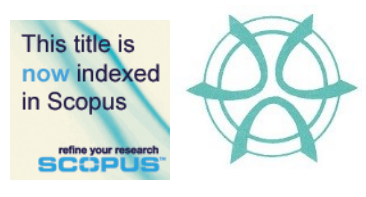

PLANNING MALAYSIA:

Journal of the Malaysian Institute of Planners

VOLUME 19 ISSUE 3 (2021), Page 351 - 362

\title{
GROSS INCOME MULTIPLIER AS A FAIRNESS INDICATOR OF TRANSACTION VALUE ON TRANSFER OF RIGHTS ON LAND AND BUILDING IN SOUTH TANGERANG
}

\author{
Nur Hendrastuti ${ }^{1}$ \\ ${ }^{1}$ State Asset and Fiscal Balance Training Center \\ FINANCIAL EDUCATION AND TRAINING AGENCY INDONESIA
}

\begin{abstract}
As the government of Indonesia targets income tax to contribute $50,1 \%$ of the overall tax revenue target in Indonesia, the Directorate General of Taxes (DGT) is compelled to maximize the excavation of tax potential. Among others, excavation of income tax potential may apply for income tax upon the transfer of rights on land and/or building. For this final income tax, tax extraction is performed by evaluating the transfer transaction value stated in the Land Deed Officer Monthly Report which should be based on the value received or obtained by the seller based on market price. Unfortunately, there is no means to ensure that the value stated by taxpayer is the actual transaction value. Also, since data on property in Indonesia is not publicly available, the real value of the transfer remains elusive. Therefore, Tax Office requires a method or technique to determine whether the stated value is a reasonable and compliant one. This research aims to examine the feasibility of Gross Income Multiplier to determine the fairness indication of transaction value stated by the taxpayer in the transfer of rights on land and/or building. By understanding the fairness of the stated value as reported in the Land Deed Officer monthly report, DGT is expected to accurately determine the fair transaction value.
\end{abstract}

Keyword: transaction value, Gross Income Multiplier, fairness indication

\footnotetext{
${ }^{1}$ Trainer at State Asset and Fiscal Balance Training Center, Ministry of Finance Republic of Indonesia Email: hestihendrastuti@gmail.com
} 
Nur Hendrastuti

Gross Income Multiplier as A Fairness Indicator of Transaction Value on Transfer of Rights on Land and Building in South Tangerang

\section{INTRODUCTION}

Tax revenue is the current focus of state revenue in Indonesia that accounts for $82.5 \%$ of the total revenues in the Indonesian State Budget of 2019 (Directorate General of Budget ,2019) generated from taxation sectors including value added tax, income tax, land and building tax, import duty, customs clearance, excise, and other taxes. In the Indonesian State Budget of 2019, income tax and value added tax are targeted to provide the highest contribution of $50.1 \%$ and $36.7 \%$, respectively. Despite the increasing target year to year, the past 6 years has never seen a fulfilment.

Addressing this missed target, the government, in this case the Directorate General of Taxes (DGT) needs to make various efforts that include excavating the potential taxation. Excavation of potential tax is an attempt to equalize a tax payment with the potential of theoretical tax owned, or an attempt to make taxpayers fulfill their potential theoretical taxes (Aribowo \& Rinaningsih, 2013). DGT, an institution primarily tasked with collecting tax revenue, analyzes the difference between tax potential and data obtained from taxpayers. The largest source of national tax revenue is non-oil income tax at $52.18 \%$ contribution (Directorate General of Taxes , 2019), which is also the largest taxes managed by central government.

Excavation of income tax potential applies to income tax upon the transfer of rights on land and/or building. For this final income tax, alternative tax extraction is feasible by evaluating the value of the transfer transaction stated in the Tax Payment Slip, a compulsory document presented to a Land Deed Officer prior to sign the deed of transfer of rights on land and/or building. The Government Regulation No. 34 of 2016 regarding Income Tax on Income from The Transfer of Rights on Land and/or Buildings and Sale and Purchase Binding Agreements on Land and/or Building (GR-34) stated that if the transfer of rights on land and/or building (L\&B) made through a sale is not influenced by associated enterprises, the value of the transfer should be reported as the tax basis and reflects the real value that the taxpayer receives. As of transfer made through exchange, waiver, submission of rights, grants, heirs, or other means that do not involve value of money, the tax basis is a value that should be received or obtained based on market price. After the deed is made, Land Deed Officer reported all acts signed in a Land Deed Officer's Monthly Report to be submitted to the head of the Tax Office of the area where the L\&B object is located. Tax Payment Slip examination and Land Deed Officer's Monthly Report submitted to the head of Tax Office shall be preliminary data in the examination of taxation obligations.

The stated value of the taxpayer's transaction needs to be examined by Tax Office because there is currently no means to ensure that the value stated by taxpayer is the actual transaction value of the transaction. Although the 
examination procedure requires an attached proof of transfer, there is no procedure to cross check the transaction value with data from the third parties, such as the beneficiary bank. Also, since data on property in Indonesia is not publicly available, the real value of the transfer remains elusive. It is different from the systems in other countries, such as the UK Residential Yield Index data in England or data on lease at the Ministry of Housing in New Zealand (Hargreaves, 2005). Any indication of misaligned or unnatural values between the stated and the provision ones, the Tax Office will clarify to taxpayers or audit the tax against the applicable provisions. Therefore, Tax Office needs a method or technique to determine whether the stated value is reasonable and compliant.

This research aims to determine whether Gross Income Multiplier (GIM) can be an alternative valuation technique to be used by the Tax Office. GIM is a method in valuation under the market data approach, and the multiplier is obtained by dividing sales price with rental price. This study used GIM because the reasonable rental price is generally easier to obtain than the reasonable selling price. This can be understood because psychologically, property owners tend to set rental price similar to the market price to boost sale. Also, tax officers, probably not an expert in valuation, need a simple method to determine the market value. Hence, it is vital to engage a simple and informative method, which expected can be achieved by using GIM.

\section{THEORETICAL AND CONCEPTUAL FRAMEWORKS}

Final Income Tax on The Transfer of Rights on Land and/or Building and Land Deed Officer Obligation to Submit the Monthly Report

Under the provisions of Article 4 Paragraph (1) of Law No. 7 of 1983 concerning Income Tax as amended by Law No. 36 year 2008 (Income Tax Law), income received or obtained from sale or transfer of property is an object of income tax. Therefore, in the event a person or a corporate receives or earns income from the transfer of property in form of land and/or building, the income is included as an object of income tax. In GR-34 is stated that the transfer of rights on L\&B is subject to a final income tax. Revenue refers to income received or acquired by the party who transferred the right through the sale, exchange, waiver, submission of rights, auction, grant, heir, or other means. Furthermore, the laws stipulated that the final income tax tariff is $2.5 \%$ of the gross amount of transfer value, except for taxpayers whose main business is to sale $L \& B$ the tariff is $1 \%$, and for the transfer of rights to the Government is $0 \%$. The transfer value used as the basis for calculating the outstanding income tax are the value that should be received (actual value).

The person or entity who receives or earns income from the transfer of rights on $L \& B$ shall be obliged to deposit his or her own income tax owed to the bank or postal collecting agent before the deed, decision, agreement, or the 
Nur Hendrastuti

Gross Income Multiplier as A Fairness Indicator of Transaction Value on Transfer of Rights on Land and

Building in South Tangerang

treatise of the auction on the transfer rights is signed by an authorized officer. The payment made for any transfer of rights on L\&B uses the tax payment slip or other administrative means on behalf of the receiver (person or entity) of the payment, then the slip will be examined by the Tax Office. While both formal and material obligations are subjected to tax examination by Tax Office, the former will receive a certificate of formal examination as a proof of fulfillment of formal obligations. Meanwhile, material examination is conducted after formal examination to ensure the correctness of the tax amount owed.

Transaction of transfer of rights that has been ratified by the authorized officer shall then be reported to the Director General of Taxes in the form of monthly report on the issuance of the deed on the transfer of $L \& B$ rights. The Land Deed Officer monthly report must be submitted for a period of 20 (twenty) days after the month of rights transfer to the Tax Office where the relevant office is registered.

\section{Fairness of Value Concept}

Fair value as the basis of income tax imposition cannot be waived from an understanding of the fairness of value in the Income Tax Law. Some regulations govern the transaction with associated enterprises, such as Article 4 Paragraph (1) Letter d, it is stated that if there is profit due to sale or because of property transfer higher or lower than market price, then market price will be used to calculate taxation obligation. This market price is considered to reflect the reasonable value of the income tax object, so it is used as the basis of tax imposition.

According to Indonesian Valuation Standard (SPI), the fair value of a fixed asset is usually the market value (Indonesian Society of Appraiser, 2018) that corresponds to the fair value used in financial accounting. SPI defines market value as an estimated amount of money earned from or paid for converting an asset or liabilities on the valuation date between buyers who intend to buy with sellers interested in selling in a transaction-free bond, reasonable marketing, and each party act prudently and without undue duress. Therefore, market value is expressed in a currency and measured as the most possible price obtained reasonably in the market. It is the best, sensible price for the seller and the most profitable price for the buyer. Meanwhile, Appraisal Institute (2013) defines market value as the most probable price, as of a specified date, in cash, or in terms equivalent to cash, or in other precisely revealed terms, for which the specified property rights should sell after reasonable exposure in a competitive market under all conditions exquisite to a fair sale, with the buyer and seller each acting prudently, knowledgeably, and for self-interest, and assuming that neither is under undue duress. 
In the sale of L\&B property, the sales value for the seller is the actual value received or based on the actual transaction. If the taxpayer does not use the market price as stipulated, DGT is authorized to redefine the magnitude of income and deduction and determine the debt as the capital to calculate the amount of taxable income for the taxpayer having associated enterprises with other taxpayers in accordance with the fairness and the dignity of the business that is not influenced by the associated enterprises. If the sale of property of $L \& B$ is influenced by associated enterprises, the sales value for the seller is the value that should be received based on reasonable market price or based on assessment by independent appraiser. Accordingly, the expertise of a valuer is necessary to determine the reasonable market price.

\section{Gross Income Multiplier Technique}

There are three common approaches in valuation: market data approach, cost approach, and income approach. One of the simple and widely used methods in market data approach is the Gross Income Multiplier (GIM) method. GIM are used to compare the income producing characteristic of properties, most often small residential income properties (Appraisal Institute, 2013). GIM measures the relationship between a property's gross income and its selling price and is a combination of an income approach and a market data approach (Lusht, 1997). Therefore, in order to use the GIM technique, sales and rental data of the property must be available. The general Formula of GIM is as follows:

$$
G I M=\frac{\text { Selling Price }}{\text { Gross Income }}
$$

Gross income used to calculate GIM is an annual gross income from the property being valued. Perceived as a simple but informative measure in property cycles (Bjorklund \& Soderberg, 1999), GIM is utilized in valuation mechanism to multiply the gross income that the property can obtain with the GIM extracted from the comparison property. For example, if GIM is 8 , the property with gross income per year Rp 40 million will be worth $\mathrm{Rp} 320$ million (Rp 40M x 8). However, two conditions should be taken into account when utilizing this method (AIREA, 1978), namely consistency in net income ratio against gross income and enough sales data on the market to acquire a clear GIM pattern. According to Lusht (1997), the similarity of property with the comparable to which the GIM will be determined includes the ratio of operating costs, prospects of profit and changes in future value, and risk. It is in accordance with Appraisal Institute (2013) that the property being analyzed should be a property that is comparable to the subject property in terms of physical, location and investment. Similarly, Zainuddin \& Yusof (2020) stated that the rental price 
Nur Hendrastuti

Gross Income Multiplier as A Fairness Indicator of Transaction Value on Transfer of Rights on Land and

Building in South Tangerang

is driven by the current rents for nearby houses (location) and the amount of mortgage that the owner has to pay.

Lusht argues that because of its simplicity, GIM is often perceived too harsh to use as a value estimating technique. However, this assumption is questionable because this technique is, in fact, common, especially for simple properties. WF Smith (in Hargreaves, 2005), stated that for some relatively homogeneous groups of residential property, gross income is a more reliable value gauge than traditional valuation methods. Confirming this, Wendt (in Hargreaves, 2005) stated that GIM is easily understood by investors, property sales agents, and lenders.

\section{RESEARCH METHODS}

This research is an exploratory descriptive study. The purpose of the descriptive research is to create a systematic, factual, and accurate adjective about the facts and properties of a specific population or region (Suryabrata, 2013). Also, exploratory study investigates a problem that has never been explored or examined and attempts to unravel the issues despite the poor circumstances and scarce research information (Bungin, 2009). This study expected to obtain a simply and feasible alternative method to evaluate the fairness of transaction value of rights transfer on $L \& B$ and to determine the follow-up of the transfer transaction reporting.

\section{Research Area}

The study was undertaken in South Tangerang City, Banten Province, a satellite city of Jakarta that experiences rapid growth and is predicted to be the center of emerging economic growth in greater Jakarta (Sulaiman, 2017). This region has the most complete urban facilities, especially with the presence of major developers, such as Bumi Serpong Damai (BSD) City, Alam Sutera, and Bintaro Jaya. Also, South Tangerang City is an area in Banten province that is directly adjacent to Jakarta and West Java provinces.

In order to obtain proof of entitlement, the transfer of rights to $L \& B$ must be ratified by the Land Deed Officer who is in charge with the district/city working area where the L\&B is located. The published data of the Ministry of Agrarian Affairs and Spatial Planning/National Land Agency revealed as many as 355 Land Deed Officers in South Tangerang who are to validate the transfer of rights.

\section{Data}

For this study, the monthly report data of the Land Deed Officer was taken from Serpong Tax Office between January and October 2019. Data on the rental and sale of land and building offers to determine the GIM in the research area were obtained from the online property offering listings in South Tangerang city. Data on property for sale and rent on the internet were obtained from the site www.olx.co.id and 
www.rumah123.com, while the price data referred to the asking price. One of the main advantages of indices constructed from asking price is their timelines (Eurostat, 2013). However, indices based on initial asking prices have a major drawback; houses can be withdrawn from market and the agreed selling price may not equal the seller's asking price. However, given the availability and accessibility of this type of data, we had them as an optional source.

The GIM was determined for the chosen housing estates: Alam Sutera and Bumi Serpong Damai (BSD). The two housing areas were selected to ensure similarities in age, size, and location characteristics of the properties from which the GIM would be measured (AIREA, 1978). Aiming to establish more thorough results, we only analyzed particular type of property in the obtained data, namely property with a land area below $500 \mathrm{~m}^{2}$. Property larger than $500 \mathrm{~m}^{2}$ was opted out because the wide variation of land and building would made it difficult to obtain comparable data. The analysis was conducted by categorizing the property based on the land area: small property $\left(<100 \mathrm{~m}^{2}\right)$, medium property $\left(100 \mathrm{~m}^{2}-200 \mathrm{~m}^{2}\right)$, and large property $\left(200 \mathrm{~m}^{2}-500 \mathrm{~m}^{2}\right)$.

\section{Stages of data analysis}

Data of rental and property sale offers were analyzed to determine the GIM in an area. Before the GIM was applied to examine the fairness of the transaction value, it was first tested whether the gross income (annual rent) could explain the variation that occurred in the value of property in the research area. Testing was conducted with regression analysis - the process of constructing a mathematical model or function to predict or determine one variable by another variable or other variables (Black, 2011). The independent variable in this analysis was the rental value, and the dependent variable was selling value. Given the lease value was proven to affect the value of property, the GIM and rental value would be utilized to analyze the fairness of the value of transactions reported in the monthly report of the Land Deed Officer.

\section{RESULTS OF RESEARCH}

The transaction data of the sales and rent used in the study were the offers for house sale and rental in two housing estates Alam Sutera and BSD which, according to Ririh (2011) were the large ones in South Tangerang. While BSD has a higher average rent value in BSD, the average selling value is only slightly higher compared to Alam Sutera (Table 1). The significantly higher median of the selling point in Alam Sutera than in BSD suggests a more dynamic trend of buying and selling transactions. Also, the standard deviation in Table 1 shows a greater variation in selling value and rent value in BSD than in Alam Sutera. 
Nur Hendrastuti

Gross Income Multiplier as A Fairness Indicator of Transaction Value on Transfer of Rights on Land and Building in South Tangerang

Table 1: Descriptive statistics of sales and rental offers In Alam Sutera and BSD housing Estate

\begin{tabular}{|c|c|c|}
\hline & $\begin{array}{c}\text { Alam Sutera Housing } \\
\text { Estate }\end{array}$ & BSD Housing Estate \\
\hline \multicolumn{3}{|l|}{ Rental value (in $R p$ 000) } \\
\hline Number of Samples & 98 & 67 \\
\hline Mean & 65,594 & 75,634 \\
\hline Median & 55,000 & 55,000 \\
\hline Deviation Standard & 36,770 & 54,358 \\
\hline \multicolumn{3}{|l|}{ Selling value (In $R p$ 000) } \\
\hline Mean & $2,983,507$ & $3,065,343$ \\
\hline Median & $2,400,000$ & $2,300,000$ \\
\hline Deviation Standard & $1,873,975$ & $2,207,962$ \\
\hline
\end{tabular}

Source: Data on rental and selling offers on www.olx.co.id and www.rumah123.com, processed

Table 2 showed that GIM tends to increase in properties with higher values as evident from the GIM's upgrade from small property groups to large property groups. This tendency occurs in both Alam Sutera and BSD, except that lower GIM was more prevalent in large property than the medium one in BSD. It is consistent with Hargreaves (2005) that stated that the yield (the opposite of GIM) will decrease as the value of the property increase.

Table 2: GIM calculation of each property group

\begin{tabular}{|c|c|c|}
\hline Type of Property & $\begin{array}{c}\text { Alam Sutera } \\
\text { Housing Estate }\end{array}$ & $\begin{array}{c}\text { BSD Housing } \\
\text { Estate }\end{array}$ \\
\hline \multicolumn{3}{|l|}{ Small Property } \\
\hline GIM & 40.1 & 39.6 \\
\hline Average Sale price (thousand Rp) & $1,830,000$ & $1,724,036$ \\
\hline Average Gross Income (m2)/year & 501.8 & 554 \\
\hline \multicolumn{3}{|l|}{ Medium Property } \\
\hline \begin{tabular}{l|l} 
GIM \\
\end{tabular} & 46.9 & 45.3 \\
\hline Average Sale price (thousand Rp) & $2,174,333$ & $2,631,944$ \\
\hline Average Gross Income (m2)/year & 459.5 & 529 \\
\hline \multicolumn{3}{|l|}{ Large Property } \\
\hline \begin{tabular}{l|l} 
GIM \\
\end{tabular} & 47.9 & 44.6 \\
\hline Average Sale price (thousand Rp) & $4,808,289$ & $6,533,929$ \\
\hline Average Gross Income (m2)/year & 491.3 & 552 \\
\hline
\end{tabular}


A regression analysis was then conducted to determine whether the independent variable of gross income in form of rental value had a significant influence on the amount of variation on the selling value (Table 3).

Table 3: Summary of Regression Analysis Results

\begin{tabular}{lrrrrrr}
\hline Type of Property & $\mathrm{R}^{2}$ & $\begin{array}{c}\text { Adjust } \\
\text { ed R }\end{array}$ & $\begin{array}{c}\text { Number of } \\
\text { Observati } \\
\text { ons }\end{array}$ & Coeff & F & $\begin{array}{c}\text { P- } \\
\text { value }\end{array}$ \\
\hline Alam Sutera & & & & & & \\
Small Property & 0.744 & 0.733 & 25 & 41.600 & 66.949 & 0.000 \\
Medium Property & 0.517 & 0.506 & 43 & 44.996 & 43.935 & 0.000 \\
Large Property & 0.303 & 0.276 & 28 & 29.986 & 11.304 & 0.002 \\
BSD & & & & & & \\
Small Property & 0.446 & 0.424 & 28 & 19.794 & 20.913 & 0.000 \\
Medium Property & 0.113 & 0.069 & 22 & 13.618 & 2.552 & 0.126 \\
Large Property & 0.254 & 0.205 & 17 & 20.105 & 5.116 & 0.039 \\
\hline & & & & & \multicolumn{3}{c}{ Source: Analysis }
\end{tabular}

The results of regression analyses of Alam Sutera housing estate showed a high coefficient of determination $\left(\mathrm{R}^{2}\right)$ values for small property which continued to decline for larger property. It is likely due to variations in larger property, such as varied characteristics of land and building areas, so it requires another variable to describe the variation. The overall models for three types of property can explain the variation that occurs at the selling value, evidenced by the higher $\mathrm{F}$ value than $\mathrm{F}$ table.

The result of regression analysis for BSD housing did not show as strong results as that of Alam Sutera despite the same tendency. Of the three models for three types of properties, the models for small property and large property significantly describe the variation in selling value, while the medium one does not. It may be due to a variation in the too-large location area. BSD is a residential area that emerges into a self-sufficient city of Jakarta sitting in a > 6,000 hectare of area (BSD City Developer, 2019). Therefore, the selling price could be influenced by the rent, but also the accessibility of clusters such as proximity to the main road, urban facilities, and other development phase. These results correspond to those expressed by Wendt (in Hargreaves, 2005) that the gross income multiplier approach represented a blending of sales comparison and income approaches to valuation, but cautions should take place when applying this valuation tool for heterogeneous property. The results are also in accordance with Hing \& Kuppusamy (2018) that proximity to infrastructure and facilities are among factors that affected home ownership in Malaysia. This is different from Alam Sutera housing which is relatively centralized because its area is only 
Nur Hendrastuti

Gross Income Multiplier as A Fairness Indicator of Transaction Value on Transfer of Rights on Land and

Building in South Tangerang

around $700 \mathrm{Ha}$, about $10 \%$ from the area of BSD. Taking these results into consideration, the next analysis of this research, which is the implementation of GIM to test the fairness of the value of transactions reported in the Land Deed Officer monthly report, would be limitedly performed for data on sale and purchase transactions in Alam Sutera housing.

The fairness indication determination of the value of transactions using the GIM was done by first specifying the mean and standard deviation for rental value per $\mathrm{m}^{2}$ area for each type of property being analyzed. Once known standard deviation for each type, we could determine the highest and lowest rental value per $\mathrm{m}^{2}$ for each property type (Table 4). This analysis could only be done to land and building properties and not for vacant land, so we did not analyze the data for transactions of vacant land.

Table 4: GIM and Rental Value/m2 per year

\begin{tabular}{lrrr}
\hline & \multicolumn{2}{c}{ Rent/m2 (Rp 000) } & \\
& Mean & Deviation Standard & GIM \\
\cline { 2 - 4 } Small Property & 501.8 & 134 & 40.1 \\
Medium Property & 459.5 & 93 & 46.9 \\
Large Property & 491.3 & 174 & 47.9 \\
\hline
\end{tabular}

Table 5 presents the results of the fairness test done with the GIM, using the highest rental value per $\mathrm{m}^{2}$ (mean +1 standard deviation) and the lowest rental value per $\mathrm{m}^{2}$ (mean -1 standard deviation).

Table 5: The Results of Fairness Measurement of Transaction Value

\begin{tabular}{lrr}
\hline & Number of Transaction & $\%$ \\
\cline { 2 - 3 } Transaction Value is fair & 55 & $38.5 \%$ \\
Transaction Value Under Estimated Value & 86 & $60.1 \%$ \\
Transaction Value Above Estimated Value & 2 & $1.4 \%$ \\
\hline Total Number of Transactions: & \multicolumn{3}{c}{ Source: Analysis }
\end{tabular}

Based on the analysis, the value of the transaction which was relatively reasonable was 54 transactions, accounted for $38,5 \%$ of the total buy and sell transactions. The remaining 86 transactions or $60,1 \%$ indicated that the value of the transaction was under the actual transaction value and two transactions declared the value of the transaction being above the fair value. Upon a closer look, we found that these two transactions arose because they were for a land 
larger than the property analyzed $\left(500 \mathrm{~m}^{2}\right)$, so we considered it inappropriate to include them in the analysis.

\section{CONCLUSION}

Although GIM is often perceived as a very simple method, it is undeniably informative and easy to understand, even for those unfamiliar with valuation. This study shows that GIM is an alternative method to estimate market value as the basis of income tax for transaction of transfer right of land and/or building $(\mathrm{L} \& \mathrm{~B})$. Most of the transaction values reported in the monthly report of the Land Deed Officer were under estimated market value, indicative of failure to meet the stipulated regulation.

\section{ACKNOWLEDGEMENT}

The authors would like to thank Tax Office of Serpong, South Tangerang City for data support and interviews.

\section{REFERENCES}

AIREA. (1978). The Appraisal of Real Estate 7th Edition. Chicago: American Institute of Real Esate Appraisers of the National Association of Realtors.

Appraisal Institute. (2013). The Appraisal of Real Estate 14th Edition. Illinois: The Appraisal Institute.

Aribowo, I., \& Rinaningsih. (2013). Modul Metode Penggalian Potensi Diklat Account Representative. Jakarta: Pusat Pendidikan dan Pelatihan Pajak.

Bjorklund, K., \& Soderberg, B. (1999). Property Cycles, Speculative Bubbles, and Gross Income Multiplier. Journal of Real Estate Research, 151-174.

Black, K. (2011). Applied Business Statistics: Making Better Business Decisions 6th Edition International Student Version. John Wiley and Sons.

BSD City Developer. (2019). About BSD City. Retrieved from www.BSDCity: https://www.bsdcity-development.com/

Bungin, B. (2009). Metodologi Penelitian Kuantitatif Komunikasi, Ekonomi, dan Kebijakan Publik serta Ilmu-ilmu Sosial Lainnya. Jakarta: Kencana.

Directorate General of Budget Ministry of Finance, Republic of Indonesia. (2019). APBN to Encourage Investment and Competitiveness Through Development of Human Resources. Jakarta: Directorate General of Budget Ministry of Finance, Republic of Indonesia.

Directorate General of Taxes . (2019). Directorate General of Taxes Annual report Year 2018. Retrieved from www.pajak.go.id: https:// www.pajak.go.id/id/laporantahunan-2018

Eurostat. (2013). Handbook on Residential Property Prices Indices (RPPIs). Methodologies \& Working Papers. Retrieved from http://epp.eurostat.ec.europa.eu/cache/ity_offpub/ks-ra-12-022/en/ks-ra-12-022en.pdf. 
Nur Hendrastuti

Gross Income Multiplier as A Fairness Indicator of Transaction Value on Transfer of Rights on Land and

Building in South Tangerang

Hargreaves, B. (2005). Exploring the Yields on Residential Investment Property. Pacific Rims Real Estate Society (PRRES) Conference. Melborne.

Hing, Y. K., \& Kuppusamy, S. (2018). Impediments to Home Ownership: Perception of Low- and Middle-Income Tenants in Selangor. Planning Malaysia: Journal of the Malaysian Institute Of Planners Volume 16 Issue 3, 357 - 368.

Indonesian Society of Appraiser. (2018). Standar Penilaian Indonesia Edisi VII (SPI). Jakarta: Indonesian Society of Appraiser.

Lusht, K. M. (1997). Real Estate Valuation: Principles and Applications. Chicago: Irwin. Republic of Indonesia. (1983). Law No. 7 regarding Income Tax.

Republic of Indonesia. (2016). Government Regulation No. 34 of 2016 regarding Income Tax On Income From The Transfer Of Rights on Land And/Or Buildings And Sale and Purchase Binding Agreements on Land and/or Building.

Ririh, N. (2011, March 03). 13 Kota Baru Tumbuh di Tangerang, Bekasi, dan Bogor. Retrieved from Kompas.com: https://properti.kompas.com/read/2011/05/03/20204260/13.kota.baru.tumbuh.di.t angerang.bekasi.dan.bogor

Sulaiman, F. (2017, March 31). Tangsel Diprediksi Jadi Pusat Pertumbuhan Ekonomi Baru. Retrieved from wartaekonomi.co.id: https:/www.wartaekonomi.co.id/read136051/tangsel-diprediksi-jadi-pusatpertumbuhan-ekonomi-baru.htm

Suryabrata, S. (2013). Metodologi Penelitian. Jakarta: PT Raja Grafindo Perkasa.

Zainuddin, Z., \& Yusof, R. M. (2020). Do Inflation, Interest Rate and Cost of Renting Affect the Price of Terrace Houses in Penang. Planning Malaysia: Journal of the Malaysian Institute of Planners Volume 18 Issue 3, 338-347.

www.olx.co.id

www.rumah123.com

Received: $12^{\text {th }}$ July 2021. Accepted: $17^{\text {th }}$ Sept 2021 